\title{
Surgical treatment of chiasmal glioma in neurofibromatosis 1
}

Michael C. Brodsky, MD, Aaron M. Fairbanks, MD, and David J. Daniels, MD, PhD

Neurology ${ }^{\circledR}$ 2020;95:40-41. doi:10.1212/WNL.0000000000009732

A 3-year-old boy with neurofibromatosis 1 had 20/40 acuity OU with normal color vision, confrontation visual fields, and optic nerves. MRI showed a large mass in the suprasellar cistern with superior and anterior displacement of the chiasm (figure, A and B). He underwent transcallosal surgical resection of the tumor, with pathology demonstrating low-grade glioma. Six months later, visual acuity was $20 / 25 \mathrm{OU}$, with normal color vision and confrontation fields. MRI showed restoration of normal suprasellar anatomy (figure, $\mathrm{C}$ and $\mathrm{D}$ ). Surgical resection can restore vision when an optic pathway

Figure Chiasmal glioma
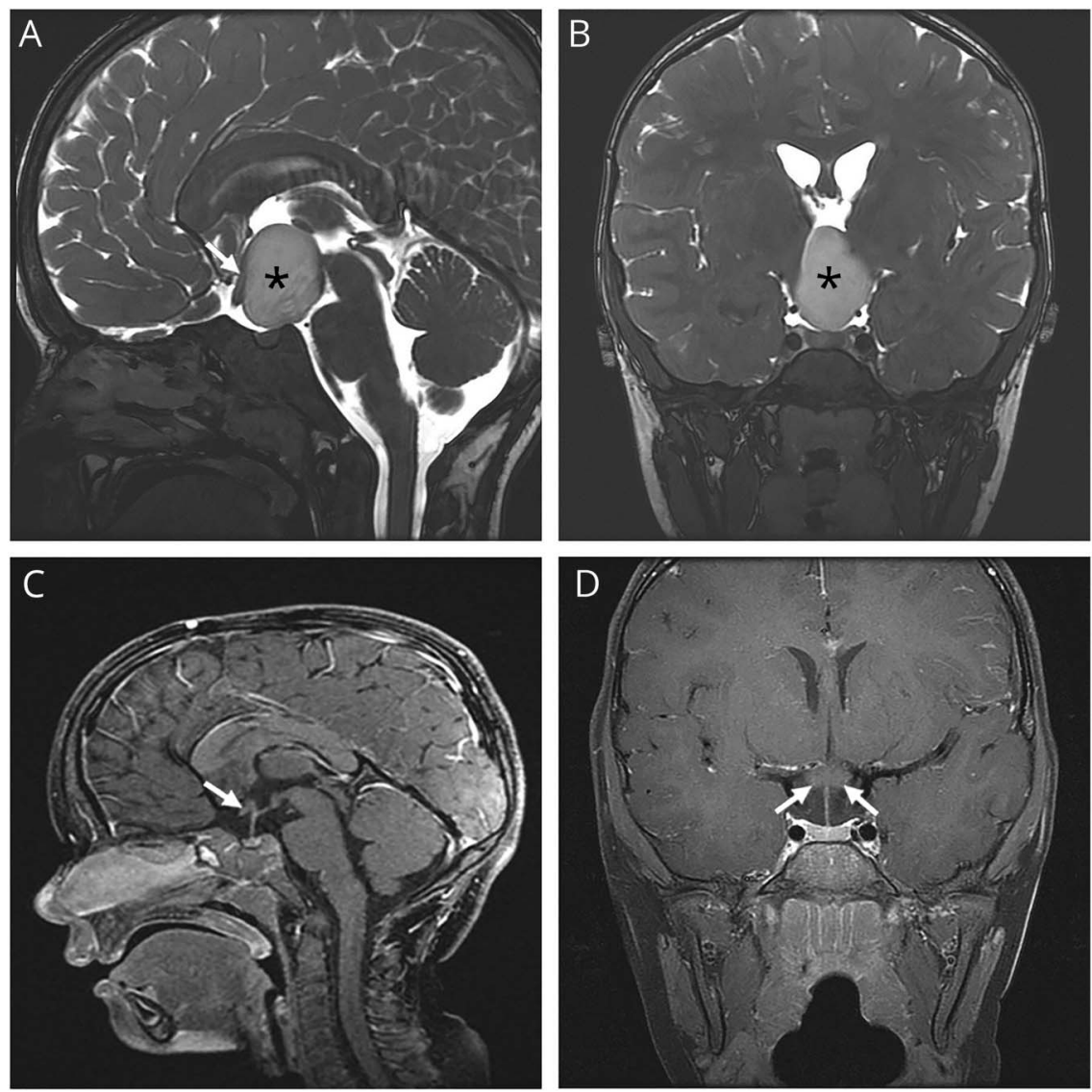

(A) Preoperative sagittal MRI shows large egg-shaped chiasmal glioma (asterisk) filling the suprasellar cistern. The chiasm (arrow) is stretched and draped over the anterior aspect of the mass. (B) Preoperative coronal MRI shows large suprasellar mass (asterisk). (C) Postoperative sagittal MRI shows restoration of the normal suprasellar anatomy and normal position of the chiasm (arrow). (D) Postoperative coronal MRI shows normal suprasellar anatomy with residual chiasmal enlargement (arrows).

\section{Correspondence}

Dr. Brodsky

Brodsky.michael@mayo.edu

From the Departments of Ophthalmology (M.C.B., A.M.F.), Neurology (M.C.B.), and Neurosurgery (D.J.D.), Mayo Clinic, Rochester, MN.

Go to Neurology.org/N for full disclosures. Funding information and disclosures deemed relevant by the authors, if any, are provided at the end of the article. 
glioma extends downward into the suprasellar cistern to extrinsically compress the chiasm. ${ }^{1,2}$

\section{Study funding}

Study funded in part by a grant from the Knights Templar Eye Foundation, Flower Mound, TX, and Mayo Clinic, Rochester, MN.

\section{Disclosure}

The authors report no relevant disclosures. Go to Neurology. org/ $\mathrm{N}$ for full disclosures.

\section{Appendix Authors}

\begin{tabular}{lll}
\hline Name & Location & Contribution \\
\hline $\begin{array}{l}\text { Michael C. } \\
\text { Brodsky, } \\
\text { MD }\end{array}$ & $\begin{array}{l}\text { Departments of } \\
\text { Ophthalmology and } \\
\text { Neurology, Mayo Clinic, } \\
\text { Rochester, MN }\end{array}$ & $\begin{array}{l}\text { Patient care, data collection, } \\
\text { clinical interpretation, } \\
\text { manuscript preparation }\end{array}$ \\
\hline $\begin{array}{l}\text { Aaron M. } \\
\text { Fairbanks, } \\
\text { MD }\end{array}$ & $\begin{array}{l}\text { Department of } \\
\text { Ophthalmology, Mayo }\end{array}$ & $\begin{array}{l}\text { Data collection, clinical } \\
\text { interpretation, manuscript } \\
\text { preparation }\end{array}$ \\
$\begin{array}{l}\text { David J. } \\
\text { Daniels, } \\
\text { MD, PhD }\end{array}$ & $\begin{array}{l}\text { Department of } \\
\text { Neurosurgery, Mayo Clinic, }\end{array}$ & $\begin{array}{l}\text { Patient care, data collection, } \\
\text { clinical interpretation, } \\
\text { manuscript preparation }\end{array}$ \\
\hline
\end{tabular}

\section{References}

1. Wisoff JH, Abbott R, Epstein F. Surgical management of exophytic chiasmatichypothalamic tumors of childhood. J Neurosurg 1990;73:661-667.

2. Ahn Y, Cho BK, Kim SK, et al. Optic pathway glioma: outcome and prognostic factors in a surgical series. Childs Nerv Syst 2006;22:1136-1142.

\section{Share Your Artistic Expressions in Neurology 'Visions'}

AAN members are urged to submit medically or scientifically related artistic images, such as photographs, photomicrographs, and paintings, to the "Visions" section of Neurology $y^{\oplus}$. These images are creative in nature, rather than the medically instructive images published in the NeuroImages section. The image or series of up to six images may be black and white or color and must fit into one published journal page. Accompanying description should be 100 words or less; the title should be a maximum of 96 characters including spaces and punctuation.

Please access the Author Center at NPub.org/authors for full submission information.

\section{Disputes \& Debates: Rapid online correspondence}

The editors encourage comments on recent articles through Disputes \& Debates:

Access an article at Neurology.org/N and click on "MAKE COMMENT" beneath the article header. Responses will be posted as rapidly as possible.

Before submitting a comment to Disputes \& Debates, remember the following:

- Disputes \& Debates is restricted to comments about articles published in Neurology within the last 8 weeks

- Read previously posted comments; redundant comments will not be posted

- Your submission must be 200 words or less and have a maximum of 5 references; the first reference must be the article on which you are commenting

- You can include a maximum of 5 authors (including yourself) 


\section{Neurology}

\section{Surgical treatment of chiasmal glioma in neurofibromatosis 1 \\ Michael C. Brodsky, Aaron M. Fairbanks and David J. Daniels}

Neurology 2020;95;40-41 Published Online before print June 11, 2020

DOI 10.1212/WNL.0000000000009732

This information is current as of June 11, 2020

\section{Updated Information \&} Services

References

Subspecialty Collections

Permissions \& Licensing

Reprints including high resolution figures, can be found at: http://n.neurology.org/content/95/1/40.full

This article cites 2 articles, 0 of which you can access for free at: http://n.neurology.org/content/95/1/40.full\#ref-list-1

This article, along with others on similar topics, appears in the following collection(s):

All Oncology

http://n.neurology.org/cgi/collection/all_oncology

Information about reproducing this article in parts (figures,tables) or in its entirety can be found online at:

http://www.neurology.org/about/about_the_journal\#permissions

Information about ordering reprints can be found online:

http://n.neurology.org/subscribers/advertise

Neurology ${ }^{\circledR}$ is the official journal of the American Academy of Neurology. Published continuously since 1951, it is now a weekly with 48 issues per year. Copyright @ 2020 American Academy of Neurology. All rights reserved. Print ISSN: 0028-3878. Online ISSN: 1526-632X.

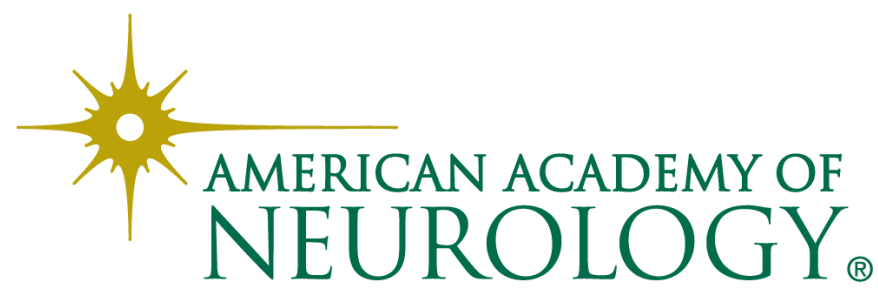

